\title{
Analysis on the Effectiveness of Extract Mixture of Anthouse Plant (Myrmecodia Pendans) and Red Pepper Vine (Piper Ornatum) as a Green Corrosion Inhibitor on the Corrosion Rate of API 5L Grade B Steel in $\mathrm{H}_{2} \mathrm{SO}_{4} 1 \mathrm{M}$ Solution
}

\author{
Tubagus Noor Rohmannudin ${ }^{a}$, Agung Purniawan, Sulistijono, Bintang Ayu Nuraeni ${ }^{\text {b }}$ \\ Department of Materials and Metallurgical Engineering, Sepuluh Nopember Institute of Technology, Surabaya, Indonesia \\ aroma r2001@yahoo.com, bbintangayu111@gmail.com
}

\begin{abstract}
The analysis of the mixture of anthouse plant (Myrmecodia pendans) and red pepper vine (Piper ornatum) in $\mathrm{H}_{2} \mathrm{SO}_{4} 1 \mathrm{M}$ solution had been studied by weight loss, Electrochemical Impedance Spectroscopy (EIS), Fourier-Transform Infrared Spectroscopy (FTIR), and Spectrometer test. The Myrmecodia pendans and Piper ornatum were chosen because they contain antioxidants that can inhibit the corrosion rate. The specimen used in this study was API 5L Grade B steel in H2SO4 1M solution. The compositions used in this study were 100\% MP : 0\% PO, 75\% MP : 25\% PO, 50\% MP : 50\% PO, 25\% MP : 75\% PO, and 0\% MP : 100\% PO (MP: Myrmecodia pendans, PO: Piper ornatum). FTIR testing result shows that a passive layer was formed by $\mathrm{O}, \mathrm{H}$, and $\mathrm{N}$ bonds. The weight loss method shows that the highest efficiency of $52.43 \%$ was achieved by $50 \%$ MP : $50 \%$ PO mix composition. Polarization testing shows that the corrosion rate decreased drastically with the addition of 50\% MP : 50\% PO mix composition, i.e., from $36.32 \mathrm{mpy}$ to $7.93 \mathrm{mpy}$, due to the passive layer formed on the steel surface. EIS results show the presence of resistance solution (Rs), charge transfer resistance (Rct), and CPE. The adsorption free energy value of the mixture of Myrmecodia pendans and Piper ornatum was $-10.02 \mathrm{~kJ} / \mathrm{mol}$ and it was a physical adsorption.
\end{abstract}

Keywords: Carbon Steel, Mixture Inhibitor, Myrmecodia pendans, Piper ornatum, $\mathrm{H}_{2} \mathrm{SO}_{4}$.

\section{Introduction}

Carbon steel is a material commonly used in various applications. For example, in the industrial world, the often-used carbon steel is API 5L grade B steel. API 5L grade B steel is applied in transportation of oil, water and natural gas. The problem that often occurs in the distribution of crude oil is the crust formation of deposits (scale). The crust is ions soluble in water, e.g., calcium, carbonate, and sulfate [1].

Anthouse plant (Myrmecodia pendans) is a plant that could be applied as organic inhibitor because of its high inhibiting efficiency of $90.36 \%$ at $500 \mathrm{ppm}$ concentration [2]. Besides that, red pepper vine (Piper ornatum) also could be applied as corrosion bioinhibitor. Red pepper vine extract contains natural antioxindants such as alkaloid, flavonoid, tannin, saponin, terpenoid, and phenols [3]. Based on the above research results, anthouse extract (Myrmecodia pendans) and red pepper vine extract (Piper ornatum) were mixed in this study to be analyzed as steel organic inhibitor in $\mathrm{H}_{2} \mathrm{SO}_{4} 1 \mathrm{M}$ environment.

Specimen used in this research was API 5L Grade B steel in $\mathrm{H}_{2} \mathrm{SO}_{4} \quad 1 \mathrm{M}$ environment. The mixture compositions used in this research were $0 \% \mathrm{MP}$ : $0 \%$ PO, $100 \%$ MP : $0 \%$ PO, $75 \%$ MP : $25 \%$ PO, $50 \%$ MP : $50 \%$ PO, $25 \%$ MP : $75 \%$ PO, and $0 \%$ MP : $100 \%$ PO, where MP is anthouse plant (Myrmecodia pendans) extract and PO is red pepper vine (Piper ornatum) extract. To analyze the characteristics of anthouse plant and red pepper vine, Fourier Transform Infra Red (FTIR) Spectroscopy was performed. Then, to evaluate the corrosion rate and the inhibitor efficiency of the anthouse plant - red pepper vine mixture, Electrochemical Impedance Spectroscopy (EIS), Polarization and weight loss tests were employed. The result of this research is hoped to encourage the mixture's application in the industrial world as an environmentally friendly corrosion inhibitor alternative.

\section{Experimental}

\subsection{Inhibitor Preparation}

Anthouse plant and red pepper vine leaves were dried and powdered. The extraction method applied to anthouse plant and red pepper vine leaves was maceration. Red pepper vine powder was dipped in $70 \%$ ethanol solution for $3 \times 24$ hours [4]. Anthouse powder was dipped in $80 \%$ ethanol for $3 \times 24$ hours [5]. The dipping result was filtered as liquid. This liquid, mixture of solvent and plant extract, was evaporated with rotary evaporator to obtain the plant extract.

\subsection{Specimen Preparation}

Specimen used was API 5L Grade B steel with the following compositions: $0.26 \% \mathrm{C}, 1.2 \% \mathrm{Mn}, 0.03 \% \mathrm{P}$, 
$0.03 \% \mathrm{~S}, 0.04 \%$ Ti. For weight loss test, the specimen was cut to a $20 \times 20 \times 3 \mathrm{~mm}$ dimension, sanded with a sandpaper, drilled on the upper central portion, and then pickled to remove the corrosion product. Before being dipped into the electrolyte solution, the specimen was pondered to obtain the initial weight. For EIS and polarization test, the same specimen was used. The specimen was cut to a $10 \times 10 \times 3 \mathrm{~mm}$ dimension, connected to a $10 \mathrm{~cm}$ long copper wire, and then molded with epoxy resin. The part of the specimen uncovered by resin was sanded to obtain smooth surface.

\subsection{Solution Preparation}

Solution used was $\mathrm{H}_{2} \mathrm{SO}_{4} 98 \%$. To obtain $1000 \mathrm{~mL}$ of $\mathrm{H}_{2} \mathrm{SO}_{4} 1 \mathrm{M}, 54.4 \mathrm{~mL} \mathrm{H}_{2} \mathrm{SO}_{4} 98 \%$ solution was taken and diluted with Aquades (distilled water) in a beaker glass until the volume was $1000 \mathrm{~mL}$.

\subsection{Weight Loss Test}

Weight loss test is done to obtain the corrosion rate in mpy (milli-inch per year) by finding difference between two weight loss tests. The first was weight loss test for single inhibitor of red pepper vine extract to obtain the efficient inhibitor concentration. Weight loss test of red pepper vine single inhibitor was done with inhibitor concentration variations of $0,1000,2000$, $3000,4000,5000 \mathrm{mg} / \mathrm{L}$ in $\mathrm{H}_{2} \mathrm{SO}_{4} 1 \mathrm{M}$ media for 36 hours, with samples taken every 6 hours. The second was weight loss test of mixed inhibitor of anthouse plant and red pepper vine extract done with variation of inhibitor mixture ratio of $0 \% \mathrm{MP}: 0 \% \mathrm{PO}, 100 \% \mathrm{MP}$ : $0 \%$ PO, $75 \%$ MP : $25 \%$ PO, 50\% MP : $50 \%$ PO, $25 \%$ MP : $75 \%$ PO, and $0 \%$ MP : $100 \%$ PO.

\subsection{Polarization Test}

Polarization test is done to obtain the corrosion rate value based on potential difference and electrical current. This polarization test used Autolab PGSTAT128N and processed with NOVA software. In this research, specimens that would be tested were specimen without inhibitor $(0 \mathrm{mg} / \mathrm{L})$, specimen with $1000 \mathrm{mg} / \mathrm{L}$ red pepper vine inhibitor, specimen with $4000 \mathrm{mg} / \mathrm{L}$ anthouse inhibitor, and specimen with inhibitor concentration ratio of 50\% MP : $50 \%$ PO.

\subsection{Electrochemical Impedance Spectroscopy (EIS) Test}

Electrochemical Impedance Spectroscopy test is aimed to obtain the corrosion mechanism occurred on a metal surface. EIS test was also performed by Autolab tool and processed by NOVA software. The result obtained was a Nyquist curve that was processed to obtain the solution resistance (Rs), charge transfer resistance (Rct), and constant phase element (CPE). In this research the specimens tested by EIS test were specimen without inhibitor $(0 \mathrm{mg} / \mathrm{L})$, specimen with $1000 \mathrm{mg} / \mathrm{L}$ red pepper vine inhibitor, specimen with $4000 \mathrm{mg} / \mathrm{L}$ anthouse inhibitor, and specimen with inhibitor concentration ratio of 50\% MP : $50 \%$ PO.

\subsection{Fourier-Transform Infrared Spectroscopy (FTIR) Test}

FTIR test is a sample quantitative test presented with peaks. The result of FTIR test is intensity and frequency. Intensity indicates the compound quantity in a specimen, while frequency indicates the compound type inside the specimen. In this research, FTIR test was used to find the functional groups of $\mathrm{O}, \mathrm{N}$, and $\mathrm{S}$ that were located in the extract of anthouse plant and red pepper vine and to evaluate the bound that could be adsorbed on the specimen surface.

\subsection{Spectrometer Test}

Spectrometer test is performed to obtain the chemical composition of a material. This test was done in the Office of Industrial Research and Standardization, Surabaya. This test was done with JIS G 1253 standard. Specimen used was API 5L Grade B steel with a dimension of $20 \times 30 \times 4 \mathrm{~mm}$.

\section{Results and Discussion}

\subsection{Weight Loss Test}

The corrosion rate and inhibitor efficiency of anthouse plant and red pepper vine single extract in $\mathrm{H}_{2} \mathrm{SO}_{4} 1 \mathrm{M}$ can be observed in the following results.

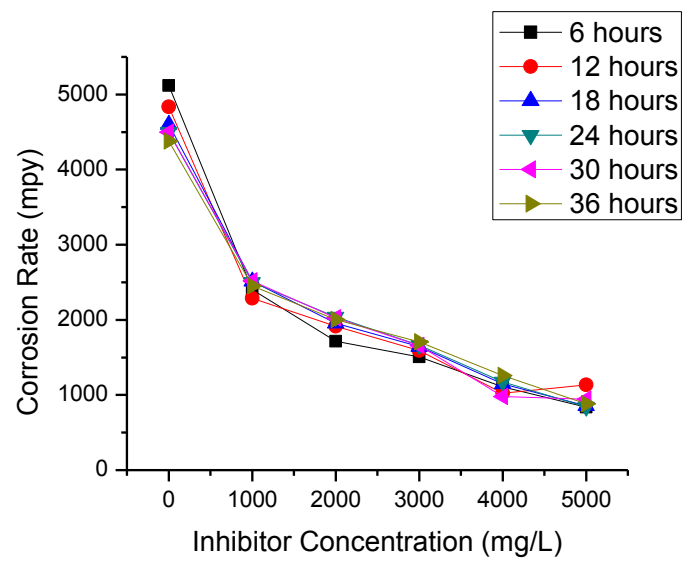

Figure 1. The effect of red pepper vine extract inhibitor concentration to corrosion rate of API 5L grade B steel

In Figure 1, it can be seen that the corrosion rate decreases as the red pepper vine inhibitor concentration is increased. The lowest corrosion rate, which is 836.04 mpy, occurs on $5000 \mathrm{mg} / \mathrm{L}$ concentration. The highest delta of corrosion rate decrease happens on $1000 \mathrm{mg} / \mathrm{L}$ addition, dropping from 5117.68 mpy to $2402.72 \mathrm{mpy}$. Therefore, it can be concluded that the addition of 1000 $\mathrm{mg} / \mathrm{L}$ is the most efficient point economically and from inhibitor addition aspect. 


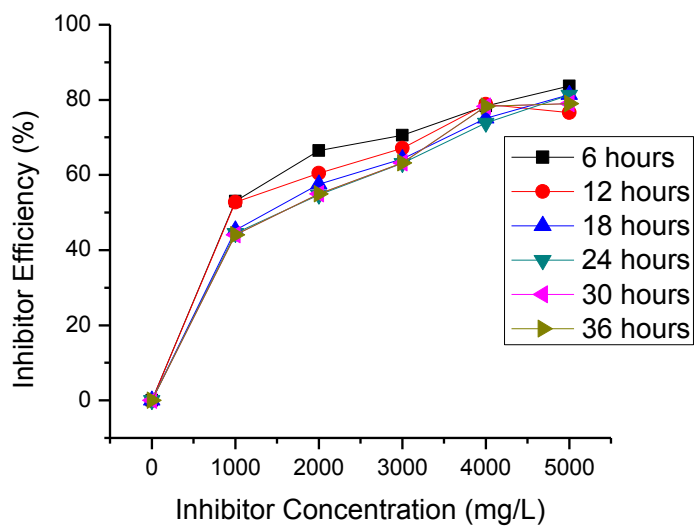

Figure 2. The effect of red pepper vine extract inhibitor concentration to inhibitor efficiency of API 5L grade B steel

Figure 2 shows the relation between red pepper vine inhibitor concentration addition and inhibitor efficiency. The highest efficiency of $83.66 \%$ happens on inhibitor addition of $5000 \mathrm{mg} / \mathrm{L}$. It also can be seen that the highest delta of efficiency increase happens on inhibitor addition of $1000 \mathrm{mg} / \mathrm{L}$. So, this condition is regarded as the most efficient from economic aspect and from inhibitor concentration addition aspect. Therefore, the concentration of $1000 \mathrm{mg} / \mathrm{L}$ was used as $100 \%$ condition for anthouse plant and red pepper vine extract mixing. The anthouse plant concentration used was $4000 \mathrm{mg} / \mathrm{L}$ [6]. Figure 3 shows the relationship of corrosion rate and inhibitor efficiency to mixing conditions of $0 \% \mathrm{MP}: 0 \% \mathrm{PO}, 100 \% \mathrm{MP}: 0 \% \mathrm{PO}$, 75\% MP : $25 \%$ PO, 50\% MP : 50\% PO, 25\% MP : $75 \%$ $\mathrm{PO}$, and $0 \% \mathrm{MP}: 100 \% \mathrm{PO}$.

In Figure 3, it can be seen that the highest corrosion rate occurs on the condition of inhibitor corrosion ratio of 0\% MP : 0\% PO, scored at $5118.468 \mathrm{mpy}$, and the lowest corrosion rate occurs on the condition of

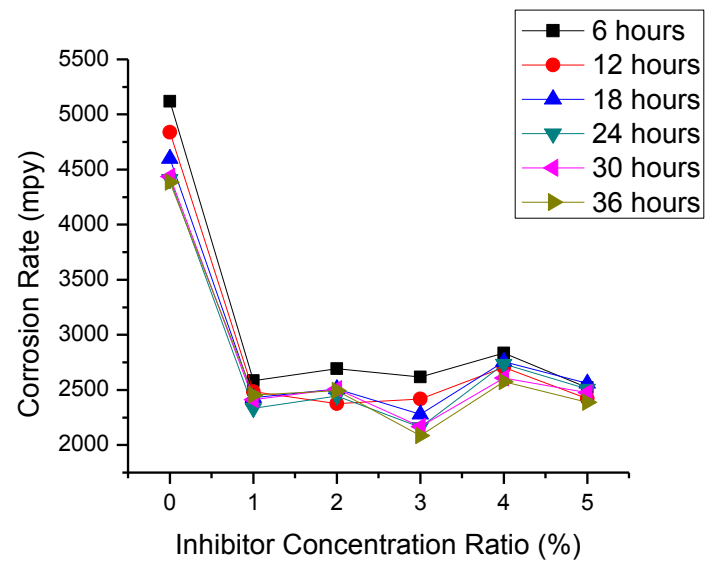

Figure 3. The effect of anthouse plant and red pepper vine mixture inhibitor concentration ratio to corrosion rate of API 5L grade B steel

Notes:

0: Inhibitor Concentration Ratio 0\% MP : $0 \%$ PO

1: Inhibitor Concentration Ratio $100 \% \mathrm{MP}: 0 \% \mathrm{PO}$

2: Inhibitor Concentration Ratio $75 \% \mathrm{MP}: 25 \% \mathrm{PO}$

3: Inhibitor Concentration Ratio 50\% MP : $50 \%$ PO

4: Inhibitor Concentration Ratio 25\% MP : $75 \%$ PO

5: Inhibitor Concentration Ratio 0\% MP : $100 \%$ PO

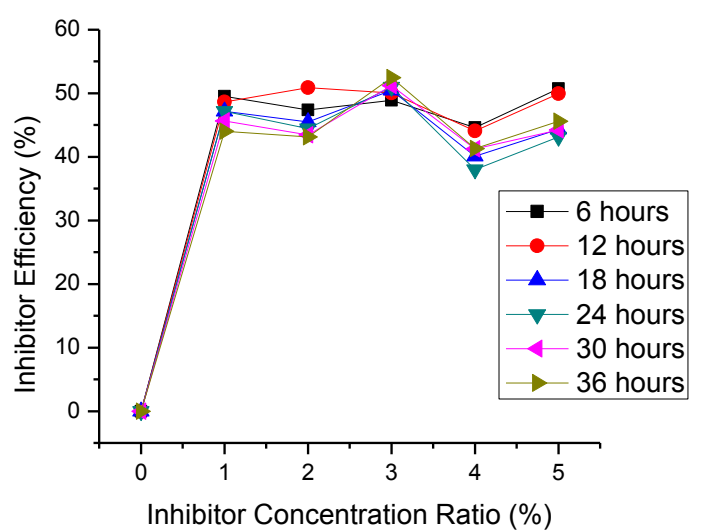

Figure 4. The effect of anthouse plant and red pepper vine mixture inhibitor concentration ratio to inhibitor efficiency of API 5L grade B steel

Notes:

0: Inhibitor Concentration Ratio 0\% MP : 0\% PO

1: Inhibitor Concentration Ratio 100\% MP : 0\% PO

2: Inhibitor Concentration Ratio 75\% MP : $25 \%$ PO

3: Inhibitor Concentration Ratio 50\% MP : 50\% PO

4: Inhibitor Concentration Ratio 25\% MP : $75 \%$ PO

5: Inhibitor Concentration Ratio 0\% MP : $100 \%$ PO

inhibitor corrosion ratio of 50\% MP : $50 \%$ PO, measured at 2086.169 mpy. The effect of anthouse plant and red pepper vine mixture inhibitor concentration ratio to inhibitor efficiency can be seen in Figure 4. Figure 4 shows that the highest efficiency of $52.43 \%$ occurs on inhibitor concentration ratio of $50 \%$ MP : $50 \%$ PO.

To analyze the correlation between corrosion rate and anthouse plant and red pepper vine extract mixture composition, on API 5L Grade B steel in $\mathrm{H}_{2} \mathrm{SO}_{4} 1 \mathrm{M}$ environment, double linear regression method was used. The obtained result of weight loss test of anthouse plant and red pepper vine inhibitor mixture was processed with double linear regression, and an equation was obtained. The equation, which shows the relationship of corrosion rate to anthouse plant and red pepper vine extract mixture composition on API 5L Grade B steel in $\mathrm{H}_{2} \mathrm{SO}_{4} 1 \mathrm{M}$, is as follows:

$$
Z=24.42 X+25.47 Y
$$

where:

$$
\begin{aligned}
& Z=\text { corrosion rate (mpy) } \\
& X=\% \text { of anthouse extract composition } \\
& Y=\% \text { of red pepper vine extract composition }
\end{aligned}
$$

The equation is only in effect if $X+Y=100 \%$.

\subsection{Polarization Test}

The results of polarization test on specimen without inhibitor addition $(0 \mathrm{mg} / \mathrm{L})$, specimen with inhibitor addition of $1000 \mathrm{mg} / \mathrm{L}$ red pepper vine, specimen with inhibitor addition of $4000 \mathrm{mg} / \mathrm{L}$ anthouse plant, and specimen with mixture concentration ratio of $50 \%$ MP : $50 \%$ PO can be seen in Figure 5.

Figure 5 shows that the trend of corrosion rate decrease with inhibitor addition is due to the shift of anodic and cathodic lines. It can also be seen that the lowest corrosion rate occurs on the mixture of $50 \%$ MP : $50 \%$ PO. 


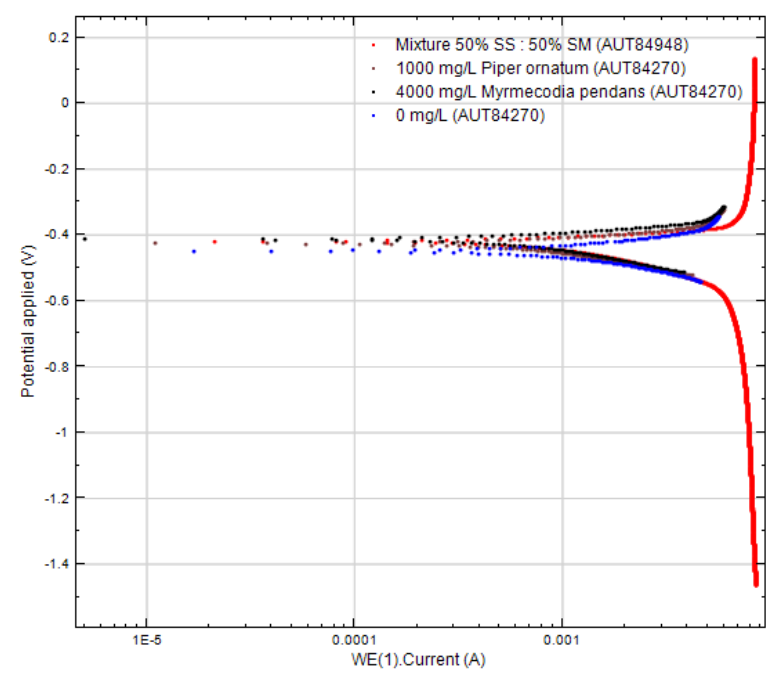

Figure 5. Polarization curve of E versus $\log (\mathrm{i})$ of API $5 \mathrm{~L}$ grade $\mathrm{B}$ steel

Table 1. Polarization test result of API 5L grade B steel

\begin{tabular}{|c|c|c|c|c|c|c|}
\hline $\begin{array}{l}\text { Concen- } \\
\text { tration }\end{array}$ & $\mathbf{E}_{\text {corr }}(\mathbf{m V})$ & $\begin{array}{c}\mathbf{i}_{\text {corr }} \\
\left(\mu \mathrm{A} / \mathbf{c m}^{2}\right)\end{array}$ & $\begin{array}{c}\text { Beta } \\
\text { cathodic } \\
(\mathrm{mV})\end{array}$ & $\begin{array}{c}\text { Beta } \\
\text { anodic } \\
(\mathrm{mV})\end{array}$ & $\begin{array}{c}\text { CR } \\
\text { (mpy) }\end{array}$ & $\begin{array}{c}\text { EI } \\
(\%)\end{array}$ \\
\hline $0 \mathrm{mg} / \mathrm{L}$ & -448.75 & 3125.80 & 84.08 & 276.92 & 36.32 & 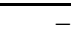 \\
\hline $\begin{array}{l}4000 \mathrm{mg} / \mathrm{L} \\
\text { Anthouse } \\
\text { Plant }\end{array}$ & 413.84 & 1138.90 & 51.00 & 107.76 & 13.23 & 63.73 \\
\hline $\begin{array}{c}1000 \mathrm{mg} / \mathrm{L} \\
\text { Red Pepper } \\
\text { Vine }\end{array}$ & 426.40 & 952.11 & 58.98 & 259.82 & 11.06 & 69.55 \\
\hline $\begin{array}{c}50 \% \text { MP : } \\
50 \% \text { PO }\end{array}$ & -420.62 & 682.78 & 39.19 & 112.10 & 7.93 & 78.16 \\
\hline
\end{tabular}

In Table 1, it can be seen that the lowest corrosion rate, valued at $7.93 \mathrm{mpy}$, occurs on the inhibitor addition condition of $50 \%$ MP : $50 \%$ PO. On the inhibitor addition of $4000 \mathrm{mg} / \mathrm{L}$ anthouse plant, the corrosion rate is $13.23 \mathrm{mpy}$, and on the inhibitor addition of $1000 \mathrm{mg} / \mathrm{L}$ red pepper vine, the corrosion rate is 11.06 mpy. Besides that, the score of $i_{\text {corr }}$ also decreases, which means that the inhibitor molecule adsorption process occurred on the surface of API 5L Grade B steel, so that the anodic and cathodic reactions were inhibited [11]. The highest efficiency in this polarization test happens on the inhibition addition of $50 \%$ MP : $50 \%$ PO, with the value of $78.16 \%$.

The scores of beta cathodic and beta anodic on inhibitor addition are significantly decreased, if compared with no inhibitor addition. We remark that anthouse plant and red pepper vine mixture inhibitor can be used as cathodic and anodic inhibitor [7].

\subsection{Electrochemical Impedance Spectroscopy (EIS) Test}

EIS test results on specimen without addition of inhibitors $(0 \mathrm{mg} / \mathrm{L})$, specimen with the inhibitor addition of $1000 \mathrm{mg} / \mathrm{L}$ red pepper vine, specimen with the inhibitor addition of $4000 \mathrm{mg} / \mathrm{L}$ anthouse plant, and specimen with a mixture of 50\% MP : $50 \%$ PO can be seen in Figure 6.

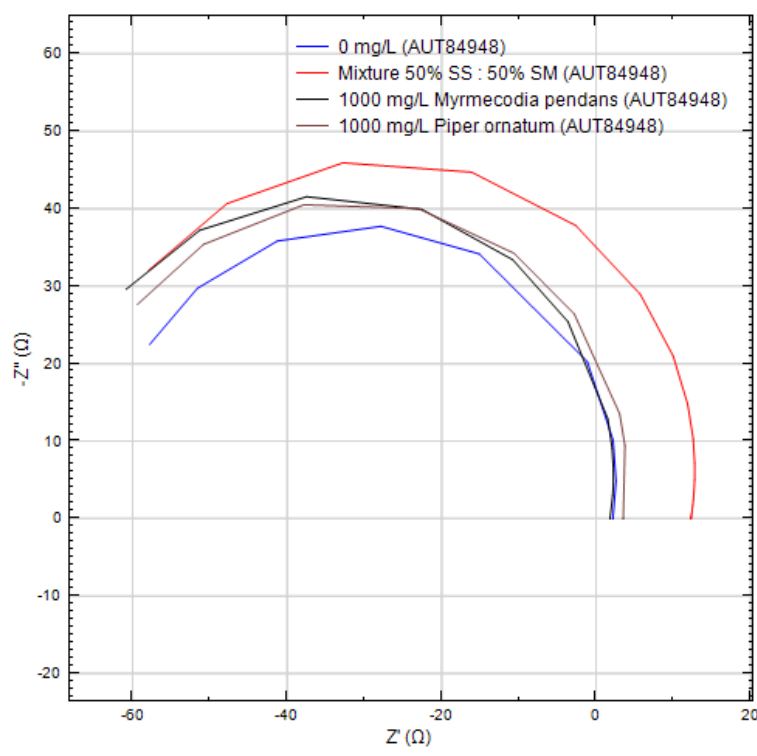

Figure 6. The fitting results of Nyquist plot on EIS test

Figure 6 shows that the curve diameter experiences magnification on the specimen with the addition of inhibitors, when compared with the specimen without addition of inhibitors. The largest diameter magnification is on the specimen with the addition of inhibitor mixture of $50 \% \mathrm{MP}: 50 \% \mathrm{PO}$. The curve is not semicircular, as this is caused by the irregularities of the specimens used (rough) [5]. Roughness of the specimen surface will cause the very large potential difference on the surface of the specimen [8].

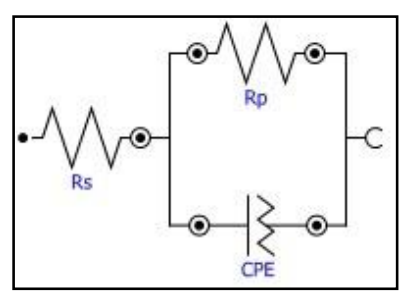

Figure 7. The equivalent circuit of fitting result of Nyquist plot on NOVA software

Figure 7 shows the equivalent circuit that explains the impedance types formed on the surface of the API 5L Grade B steel. It appears that there are resistance solution (Rs), polarization resistance ( $\mathrm{Rp}$ ) and constant phase element (CPE). It can be seen in Figure 7 that the first reaction that occurs in the system is the emergence of resistance solution (Rs), which was caused by the solution that happened on standard electrode and working electrode. The equivalent circuit also contains the constant phase element (CPE). CPE is an empirical impedance associated with the frequency dispersion associated with irregularities in the surface of the specimen [9]. This indicates that the specimen used for EIS test was uneven, hence CPE appeared. Polarization resistance ( $\mathrm{Rp})$ is equal to the charge transfer resistance (Rct). Rct arising from metal surface interaction with the electrolyte solution results in dissolution of atoms on a metal surface. 
Table 2. Fitting results of Nyquist plot on API 5L grade B steel

\begin{tabular}{ccccr}
\hline $\begin{array}{c}\text { Inhibitor } \\
\text { concentration }\end{array}$ & Rs $(\boldsymbol{\Omega})$ & Ret $(\boldsymbol{\Omega})$ & CPE & EI (\%) \\
\hline $0 \mathrm{mg} / \mathrm{L}$ & -62.39 & 64.57 & 1.0065 & - \\
\hline $\begin{array}{c}4000 \mathrm{mg} / \mathrm{L} \\
\text { Anthouse Plant }\end{array}$ & -69.49 & 71.29 & 1.0069 & $9.42 \%$ \\
\hline $\begin{array}{c}1000 \mathrm{mg} / \mathrm{L} \\
\text { Red Pepper } \\
\text { Vine }\end{array}$ & -66.65 & 70.16 & 1.0067 & $7.96 \%$ \\
\hline $\begin{array}{c}50 \% \mathrm{MP}: \\
50 \% \text { PO }\end{array}$ & -66.84 & 79.12 & 1.0065 & $18.39 \%$ \\
\hline
\end{tabular}

Table 2 shows that the highest efficiency, i.e. $18.39 \%$, occurs on inhibitor addition of $50 \% \mathrm{MP}: 50 \%$ PO. The inhibitor addition of $4000 \mathrm{mg} / \mathrm{L}$ anthouse plant generates efficiency of $9.42 \%$, and the inhibitor addition of $1000 \mathrm{mg} / \mathrm{L}$ red pepper vine generates efficiency of $7.96 \%$. The inhibitor efficiency result is different with the result of weight loss test, and this was caused by the difference of experiment time [10]. The Rct score increases with the inhibitor addition, and this was caused by passivation formed on the API 5L Grade $\mathrm{B}$ steel surface, that was originated from the bond of $\mathrm{Fe}$ with the groups of $\mathrm{O}, \mathrm{C}$, and $\mathrm{H}$ that present in anthouse plant and red pepper vine extract [5].

\subsection{Fourier-Transform Infrared Spectroscopy (FTIR) Test}

The result of red pepper vine's FTIR test in the form of FTIR spectrum and the analysis of functional groups and compounds are presented in this subsection.

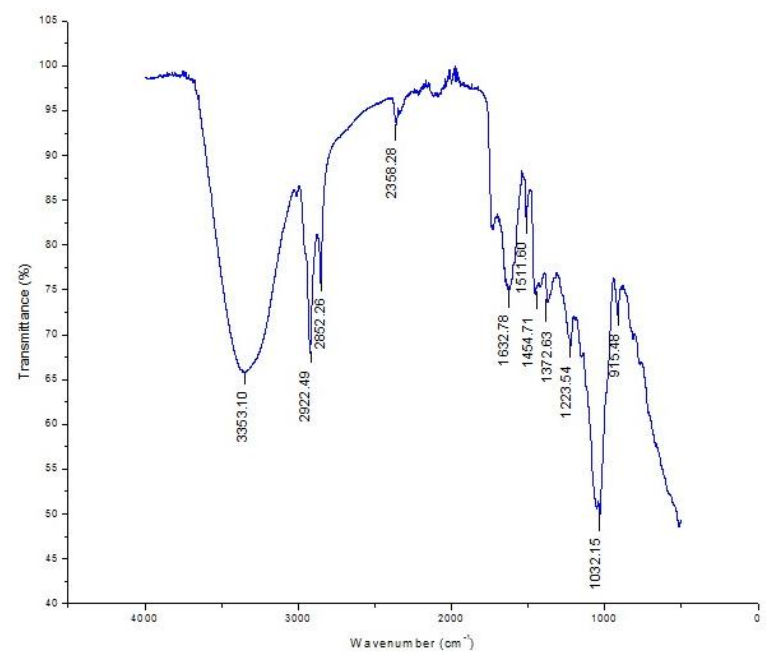

Figure 8. FTIR spectrum of red pepper vine

Figure 8 shows the result of FTIR spectrum of red pepper vine that illustrates the relation between wavenumber and transmittance. In Figure 8, different main wavenumber results are shown; they are 915.48, 1032.15, 1223.54, 1372.63, 1454.71, 1511.60, 1632.78, $2358.28,2852.26,2922.49$, and $3353.10 \mathrm{~cm}^{-1}$. Table 3 presents the functional groups analysis of red pepper vine.
Table 3. FTIR analysis of functional groups and compounds of red pepper vine

\begin{tabular}{|c|c|c|c|}
\hline No. & $\begin{array}{c}\text { Wavenumber } \\
\left(\mathrm{cm}^{-1}\right)\end{array}$ & Bond Type & Functional Groups \\
\hline 1 & 915.48 & $\mathrm{O}-\mathrm{H}$ & Carboxylic acid \\
\hline 2 & 1032.15 & $\mathrm{C}-\mathrm{N}$ & Aliphatic amine \\
\hline 3 & 1223.54 & $\mathrm{C}-\mathrm{O}$ & $\begin{array}{l}\text { Alcohol, carboxylic acid, ester, } \\
\text { ether }\end{array}$ \\
\hline 4 & 1372.63 & $\mathrm{C}_{-} \mathrm{H}$ & Alkanes \\
\hline 5 & 1454.71 & $\mathrm{C}-\mathrm{H}$ & AIKanes \\
\hline 6 & 1511.60 & $\mathrm{~N}-\mathrm{O}$ & Nitrocompounds \\
\hline 7 & 1632.78 & $\mathrm{C}=\mathrm{C}$ & Alkenes \\
\hline 8 & 2358.28 & Triple & - \\
\hline $\begin{array}{r}9 \\
10 \\
\end{array}$ & $\begin{array}{l}2852.26 \\
2922.49\end{array}$ & $\mathrm{C}-\mathrm{H}$ & Alkanes \\
\hline 11 & 3353.10 & $\begin{array}{l}\mathrm{N}-\mathrm{H} \\
\mathrm{O}-\mathrm{H}\end{array}$ & $\begin{array}{l}\text { Amines, amides } \\
\text { Alcohols, phenols }\end{array}$ \\
\hline
\end{tabular}

Table 3 shows that the wavenumber $915.48 \mathrm{~cm}^{-1}$ has $\mathrm{O}-\mathrm{H}$ bond with the functional group of carboxylic acid, while the wavenumber $1032.15 \mathrm{~cm}^{-1}$ has $\mathrm{C}-\mathrm{N}$ bond that is the functional group of aliphatic amine. Wavenumber $1223.54 \mathrm{~cm}^{-1}$ has $\mathrm{C}-\mathrm{O}$ bond that assumes the functional groups of alcohol, carboxylic acid, ester, and ether. The bonds of $\mathrm{C}-\mathrm{H}$ present in wavenumber $1372.63 \mathrm{~cm}^{-1}, 1454.71 \mathrm{~cm}^{-1}, 2852.26 \mathrm{~cm}^{-1}$, and $2922.49 \mathrm{~cm}^{-1}$ are with alkane functional group. In wavenumber $1511.60 \mathrm{~cm}^{-1}$ nitrogen compound is assumed with $\mathrm{N}-\mathrm{O}$ bond, and in wavenumber 1632.78 $\mathrm{cm}^{-1}$ the double bond between $\mathrm{C}$ and $\mathrm{C}$ (or, $\mathrm{C}=\mathrm{C}$ ) is present with functional group of alkene. In wavenumber $2358.28 \mathrm{~cm}^{-1}$ the triple bond or aromatic ring is present, but the type of compound or functional group that composes the form of bond is unknown. This bond will produce $\pi$ electron that functions as facilitator of charge transfer from inhibitor to metal surface [11]. In wavenumber $3353.10 \mathrm{~cm}^{-1}$ two bond forms; the first one is $\mathrm{N}-\mathrm{H}$ of amine or amide functional group and the second one is $\mathrm{O}-\mathrm{H}$ with alcohol or phenol functional group. The bonds that are present in red pepper vine such as $\mathrm{O}-\mathrm{H}, \mathrm{C}-\mathrm{N}, \mathrm{C}-\mathrm{O}, \mathrm{C}-\mathrm{H}, \mathrm{N}-\mathrm{O}, \mathrm{C}=\mathrm{C}$, and $\mathrm{N}-\mathrm{H}$ are associated with flavonoid which is one type of antioxidant [11].

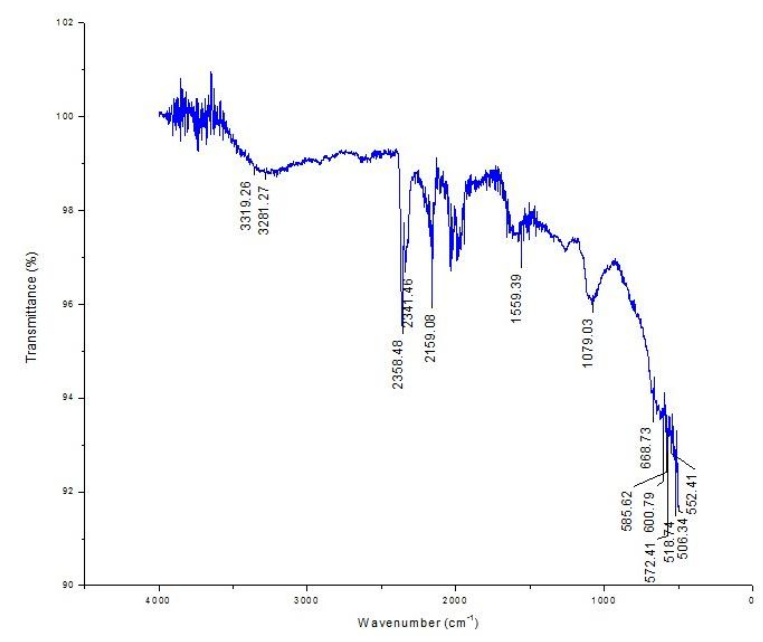

Figure 9. FTIR spectrum of passivation layer on API $5 \mathrm{~L}$ grade $\mathrm{B}$ steel 
Figure 9 shows the result of FTIR spectrum of passivation layer on API 5L Grade B steel that depicts the relation between wavenumber and transmittance. The different wavenumbers shown in Figure 9 are 506.34, 518.74, 552.41, 572.41, 585.62, 600.79, 668.73, 1079.03, 1559.39, 2159.08, 2341.46, 2358.48, 3281.27, and $3319.26 \mathrm{~cm}^{-1}$. The result of functional group analysis of red pepper vine extract is shown in Table 4.

Table 4. FTIR analysis of functional groups and compounds of passivation layer on API 5L grade B steel

\begin{tabular}{|c|c|c|c|}
\hline No. & $\begin{array}{c}\text { Wavenumber } \\
\left(\mathrm{cm}^{-1}\right)\end{array}$ & Bond Type & Functional Group \\
\hline 1 & 506.34 & \multirow{6}{*}{$\mathrm{C}-\mathrm{Br}$} & \multirow{6}{*}{ Bromide } \\
\hline 2 & 518.74 & & \\
\hline 3 & 552.41 & & \\
\hline 4 & 572.41 & & \\
\hline 5 & 585.62 & & \\
\hline 6 & 600.79 & & \\
\hline 7 & 668.73 & $\mathrm{C}-\mathrm{Br}$ & Alkyl halide \\
\hline 8 & 1079.03 & $\mathrm{C}-\mathrm{N}$ & Aliphatic amine \\
\hline 9 & 1559.39 & $\mathrm{~N}-\mathrm{O}$ & Nitrous compound \\
\hline 10 & 2159.08 & $\mathrm{C} \equiv \mathrm{C}$ & Alkenes \\
\hline 11 & 2341.46 & \multirow{2}{*}{ Triple } & \multirow{2}{*}{-} \\
\hline 12 & 2358.48 & & \\
\hline \multirow{2}{*}{13} & \multirow{2}{*}{3281.27} & $\mathrm{~N}-\mathrm{H}$ & Amine, amide \\
\hline & & $\mathrm{O}-\mathrm{H}$ & Alcohol, phenol \\
\hline \multirow{2}{*}{14} & \multirow{2}{*}{3319.26} & $\mathrm{~N}-\mathrm{H}$ & Amine, amide \\
\hline & & $\mathrm{O}-\mathrm{H}$ & Alcohol, phenol \\
\hline
\end{tabular}

Table 4 shows that $\mathrm{C}-\mathrm{Br}$ bond is formed as bromide functional group in wavenumber 506.34, 518.74, 552.41, 572.41, 585.62, and $600.79 \mathrm{~cm}^{-1}$. In wavenumber $668.73 \mathrm{~cm}^{-1} \mathrm{C}-\mathrm{Br}$ is also formed but the functional group is alkyl halide. In wavenumber $1079.03 \mathrm{~cm}^{-1} \mathrm{C}-\mathrm{N}$ bond is formed with functional group of aliphatic amine. In wavenuber $1559.39 \mathrm{~cm}^{-1}$ nitrous compound is formed with $\mathrm{N}-\mathrm{O}$ bond, while in wavenumber $2159.08 \mathrm{~cm}^{-1}$ triple bond of $\mathrm{C}$ is formed as alkene. In wavenumber 2341.46 and $2358.48 \mathrm{~cm}^{-1}$ triple bond or aromatic ring is formed but the compound is unknown; the same as what happened with the FTIR of red pepper vine. In wavenumber 3281.27 and $3319.26 \mathrm{~cm}^{-1}$, bonds of $\mathrm{N}-\mathrm{H}$ and $\mathrm{O}-\mathrm{H}$ are formed with amine and amide as the functional group of $\mathrm{N}-\mathrm{H}$ and alcohol and phenol as the functional group of $\mathrm{O}-\mathrm{H}$. The results above show that adsorption had happened from the mixing of anthouse plant and red pepper vine inhibitor on the surface of API 5L Grade B steel. The adsorbed bonds are $\mathrm{C}-\mathrm{N}, \mathrm{N}-\mathrm{O}, \mathrm{N}-\mathrm{H}, \mathrm{O}-\mathrm{H}$, and the unknown triple bond which forms the $\pi$ electron. Those bonds are identified as flavonoid which functions as antioxidant to protect the metal surface.

\subsection{Spectrometer Test}

The results of spectrometer test on the API 5L Grade B steel can be seen in Table 5. Based on the results on Table 5, it could be concluded that API 5L Grade B steel is a low carbon steel because of the C content that is below $0.3 \%$. Beside the carbon, other elements present are $\mathrm{Si}, \mathrm{Mn}, \mathrm{P}, \mathrm{S}, \mathrm{Cu}, \mathrm{Ni}, \mathrm{Cr}, \mathrm{Mo}$, and
Al. Elements like Ni, Mn, Cr, and Mo could make a metal become corrosion resistant. But the content percentages of those elements in API 5L Grade B steel are very small, so the steel is still prone to corrosion. Hence, API 5L Grade B steel needs a system of corrosion protection, and one of them is inhibitor.

Table 5. Analysis of spectrometer test result on API 5L grade B steel

\begin{tabular}{cc}
\hline Element & Chemical Composition $(\%)$ \\
\hline $\mathrm{C}$ & 0.19526 \\
$\mathrm{Si}$ & 0.18809 \\
$\mathrm{Mn}$ & 0.37488 \\
$\mathrm{P}$ & 0.01538 \\
$\mathrm{~S}$ & 0.01252 \\
$\mathrm{Cu}$ & 0.01259 \\
$\mathrm{Ni}$ & 0.02316 \\
$\mathrm{Cr}$ & 0.04622 \\
$\mathrm{Mo}$ & 0.00913 \\
$\mathrm{Al}$ & 0.00122 \\
$\mathrm{Fe}$ & 99.12200 \\
\hline
\end{tabular}

\section{Summary and Suggestions}

\subsection{Summary}

After various experiments and analyses were done on red pepper vine and anthouse plant inhibitor mixture, it could be summarized that:

1. The mixing of anthouse plant and red pepper vine inhibitor extract could be used as green corrosion inhibitor.

2. Efficiency of $4000 \mathrm{mg} / \mathrm{L}$ anthouse plant single inhibitor reached $49.5 \%$ with corrosion rate measured $2584.731 \mathrm{mpy}$, efficiency of 1000 $\mathrm{mg} / \mathrm{L}$ red pepper vine single inhibitor reached $50.74 \%$ with corrosion rate measured 2521.446 mpy, and efficiency of 50\% MP : $50 \%$ PO mixture was $52.43 \%$ with corrosion rate measured 2086.169 mpy. This result proves that mixed inhibitor is more effective than single inhibitor.

3. Inhibition mechanism of mixture inhibitor of anthouse plant and red pepper vine is physical adsorption and passivation layer formed on metal surface.

\subsection{Suggestions}

1. It is suggested to do Soxhlet extraction method for red pepper vine to obtain more phenolic compounds.

2. It is suggested to increase the quantity of anthouse plant and red pepper vine mixture inhibitor composition to obtain more accurate data.

\section{References}

1. Halimatuddahliana, Pencegahan Korosi dan Scale pada Proses Produksi Minyak Bumi [Corrosion and Scale Prevention in the Production Process of 
Petroleum Oil], Research Report, University of North Sumatra (Indonesia): Department of Chemical Engineering, 1999.

2. Pradityana, A., Sulistijono, and Shahab, A., Effectiveness of Myrmecodia Pendans Extract as Eco-Friendly Corrosion Inhibitor for Material API 5L Grade $\mathrm{B}$ in $3.5 \% \mathrm{NaCl}$ Solution, Advanced Materials Research, 789, 2013, pp. 484-491, doi: 10.4028/www.scientific.net/AMR.789.484.

3. Wicaksono, F.M., Sari, D.S.P., Sekti, B.H., Sari, Y., Natalia, E., Lyrawati, D., and Febriyanti, A.P., Piperantha: Inovasi Terapi Kombinasi Ekstrak Daun Salam (Eugenia Polyantha) dan Sirih Merah (Piper Crocatum) terhadap Peningkatan Aktivitas Fas/FasL pada Regresi Pertumbuhan Kanker Serviks Secara In Vitro [Piperantha: Therapy Innovation of Combined Extract of Bay Leaf (Eugenia Polyantha) and Red Betel (Piper Crocatum) for Increasing Fas/Fas-L Activity on Growth Regression of Cervical Cancer In-Vitro], e-Proceedings of PKM$P, 2013$.

4. Harborne, J.B., Metode Fitokimia: Penuntun Cara Modern Menganalisis Tumbuhan [Phytochemical Methods: A Guide to Modern Techniques of Plant Analysis; translated by Padmawinata, K.], Bandung (Indonesia): ITB, 1987.

5. Nabilla, S.C., Aplikasi Sarang Semut (Myrmecodia Pendans) sebagai Inhibitor Korosi pada Baja API 5L Grade B dan AISI 1010 dalam Media 3,5\% NaCl [Application of Anthouse Plant (Myrmecodia Pendans) as a Corrosion Inhibitor for API $5 L$ Grade B and AISI 1010 Steels in $3.5 \% \mathrm{NaCl}$ Solution], Undergraduate Thesis, Sepuluh Nopember Institute of Technology (Indonesia): Department of Materials and Metallurgical Engineering, 2014.

6. Putri, I.N.A., Pengaruh Konsentrasi Inhibitor Ekstrak Sarang Semut terhadap Laju Korosi Baja API $5 \mathrm{~L}$ Grade $\mathrm{B}$ dalam Media $\mathrm{H}_{2} \mathrm{SO}_{4} 1 \mathrm{M}$ [Effects of Inhibitor Concentration of Anthouse Plant Extract towards Corrosion Rate of API 5L Grade B Steel in $\mathrm{H}_{2} \mathrm{SO}_{4} \quad 1 M$ Solution], Undergraduate Thesis, Sepuluh Nopember Institute of Technology (Indonesia): Department of Materials and Metallurgical Engineering, 2014.
7. Darmawan, O., Studi Green Corrosion Inhibitor Ekstrak Daun Bayam Merah (Amaranthus Gangeticus) pada Baja Karbon Rendah dalam Larutan $1 \mathrm{M} \mathrm{HCl}$ dengan Metode Polarisasi dan EIS [Study of Red Spinach Leaves (Amaranthus Gangeticus) Extract as a Green Corrosion Inhibitor for Low-Carbon Steel in $\mathrm{HCl} 1 \mathrm{M}$ Solution Using Polarization and EIS Methods], Master Thesis, University of Indonesia: Department of Metallurgical dan Materials Engineering, 2012.

8. Ichwani, M.R., Pengaruh Kekasaran Permukaan terhadap Laju Korosi Baja API 5L dalam Larutan Asam, Basa, dan Garam [Effects of Surface Roughness towards Corrosion Rate of API 5L Steel in Acid, Alkaline, and Salt Solutions], Undergraduate Thesis, Brawijaya University (Indonesia): Department of Mechanical Engineering, 2014.

9. Brug, G.J., van den Eeden, A.L.G., SluytersRehbach, M., and Sluyters, J.H., The Analysis of Electrode Impedances Complicated by the Presence of a Constant Phase Element, Journal of Electroanalytical Chemistry and Interfacial Electrochemistry, 176(1-2), pp. 275-295, Sep. 1984, doi: 10.1016/S0022-0728(84)80324-1.

10. Nadhir, F., Pemanfaatan Bio Inhibitor Daun Sukun terhadap Laju Korosi pada Baja API 5L Grade B di Lingkungan 3,5\% $\mathrm{NaCl}$ dan $\mathrm{IM} \mathrm{H}_{2} \mathrm{SO}_{4}$ [Utilizing Breadfruit Leaves as a Bio Inhibitor towards Corrosion Rate of API $5 L$ Grade B Steel in 3.5\% $\mathrm{NaCl}$ and $\mathrm{H}_{2} \mathrm{SO}_{4} 1 \mathrm{M}$ Environments], Undergraduate Thesis, Sepuluh Nopember Institute of Technology (Indonesia): Department of Materials and Metallurgical Engineering, 2014.

11. Akbar, H.R., Isolasi dan Identifikasi Golongan Flavonoid Daun Dandang Gendis (Clinacanthus Nutans) Berpotensi sebagai Antioksidan [Isolation and Identification of Flavonoid from Snake Grass Leaves (Clinacanthus Nutans) Having Antioxidant Potential], Undergraduate Thesis, Bogor Institute of Agriculture (Indonesia): Department of Chemistry, 2010. 